\title{
Cytogenetic characterization and gene expression profiling in the rat reflux-induced esophageal tumor model
}

\author{
Pramod Bonde, MD, MS, FRCS, a Guoping Sui, MD, ${ }^{\text {b }}$ Surajit Dhara, PhD, ${ }^{\text {b }}$ Jiaai Wang, BS, ${ }^{\mathrm{c}}$ Apoorv Broor, MD, ${ }^{\mathrm{c}}$ \\ Irene F. Kim, PhD, ${ }^{d}$ John E. Wiley, PhD, ${ }^{e}$ Guy Marti, MD, ${ }^{c}$ Mark Duncan, MD, ${ }^{c}$ Elizabeth Jaffee, MD, ${ }^{f}$ \\ Elizabeth Montgomery, MD, ${ }^{b}$ Anirban Maitra, MBBS, ${ }^{\text {b,f }}$ and John W. Harmon, MD ${ }^{c}$
}

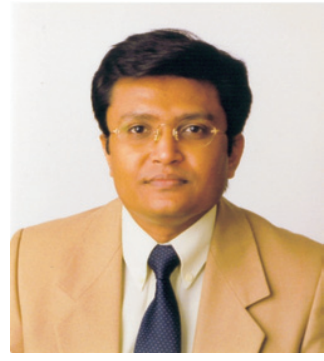

Dr Bonde

Supplemental material is available online.

From the Departments of Cardiothoracic Surgery, ${ }^{\mathrm{a}}$ Pathology, ${ }^{\mathrm{b}}$ Medicine, ${ }^{\mathrm{d}}$ and Oncology, Johns Hopkins University School of Medicine, Baltimore, Md; the Department of Surgery, ${ }^{\mathrm{c}}$ Johns Hopkins Bayview Medical Center, Baltimore, Md; and the Department of Pediatrics, ${ }^{\mathrm{e}}$ Brody School of Medicine, East Carolina University, Greenville, NC.

Pramod Bonde is supported by the RVH research Fellowship, Dowager Countess Eleanor Peel Foundation Fellowship, RRG funding from Queens University, and St Jude Scholarship of Society of Cardiothoracic Surgeons of Great Britain and Ireland. Guoping Sui is supported by the International Collaborative Genetics Research Training Program (ICGRTP), NIH D43 TW06176. Anirban Maitra is supported by NCI R01CA113669. This work is also supported by the Jeanotte Foundation for Esophageal Cancer Research at Johns Hopkins University.

Received for publication Jan 31, 2006; revisions received July 11, 2006; accepted for publication July 17, 2006.

Address for reprints: John Harmon, MD, Johns Hopkins Bayview Medical Center, Room 5C, Bldg A, 4940 Eastern Ave, Baltimore, MD 21224 (E-mail: jharmon@jhmi. edu).

J Thorac Cardiovasc Surg 2007;133:763-9

$0022-5223 / \$ 32.00$

Copyright () 2007 by The American Association for Thoracic Surgery

doi:10.1016/j.jtcvs.2006.07.044
Objectives: The reasons for the increasing incidence of esophageal adenocarcinoma are not clear. A causal relation between gastroesophageal reflux disease and esophageal adenocarcinoma has been suggested. Support for this comes from the development of esophageal adenocarcinoma in the rat reflux model. However, to date, no systematic characterization of the tumors derived from this model has been reported.

Methods: We induced biliary reflux by creating esophagojejunal anastomoses in 12 Sprague-Dawley rats. The experiment was terminated at 9 months, and rat esophagi were harvested for histopathologic documentation of reflux-associated changes and evidence of tumor formation. Three cell lines were established from 2 of the reflux-associated tumors. We tested the ability of these cells to grow in vitro in tissue culture and in vivo as xenografts in an orthotopic location at the gastroesophageal junction. Furthermore, we performed a cytogenetic analysis and determined the array-based gene expression profiles of these 3 rodent carcinoma lines compared with normal esophageal mucosa.

Results: At 9 months, 12 of 12 rodents had histologic features of metaplastic columnar epithelium in the esophagus, with 7 having invasive carcinomas with glandular differentiation (either adenocarcinomas or adenosquamous carcinomas). The 3 cell lines established from 2 reflux-associated tumors were capable of sustained in vitro propagation and grew successfully as xenografts in both subcutaneous and orthotopic locations, confirming the tumorigenic nature of these lines. Despite their establishment from primary tumors with glandular features, the histology of the xenografts was that of well-differentiated squamous carcinomas. Karyotype analyses demonstrated cytogenetic heterogeneity and aneuploidy; furthermore, translocation (7:11) was present in all 3 lines. Array-based gene expression profiling confirmed upregulation of several cancerrelated genes important in human esophageal cancer. Quantitative reverse transcriptionpolymerase chain reaction was used to confirm the differential expression of selected transcripts (vascular endothelial growth factor $[V E G F]$, polo-like kinases $[P L K]$, cyclin dependent kinase $4[C D K 4]$, hypoxia-inducible factor $1 \alpha[H I F 1 \alpha]$, and insulin-like growth factor $1[I G F-1])$ in comparison with nonneoplastic esophageal mucosal scrapings.

Conclusions: The rodent reflux model is capable of inducing metaplastic epithelial changes simulating Barrett esophagus, as well as subsequent neoplastic transformation, at a high frequency. Cell lines have been established from these tumors that are capable of in vitro and in vivo passaging. The rodent reflux model should be a valuable model for studying therapy and chemoprevention efforts for Barrett esophagus, whereas the established cell lines provide a useful resource for drug discovery and other high-throughput studies.

$\mathrm{T}$ The increasing incidence of esophageal adenocarcinoma has necessitated a search for the causes leading to this epidemic. ${ }^{1}$ Epidemiologic studies have confirmed that this increase in the incidence of esophageal adenocarcinoma is strongly related to a similar increase in the incidence of gastroesophageal reflux disease. ${ }^{2}$ How gastroesophageal reflux might be responsible for the development of 


\author{
Abbreviations and Acronyms \\ $C D K-4=$ cyclin dependent kinase 4 \\ $H I F 1 \alpha=$ hypoxia-inducible factor $1 \alpha$ \\ $I G F-1=$ insulin-like growth factor \\ $P L K \quad=$ polo-like kinases \\ $R T-P C R=$ reverse transcription-polymerase chain \\ reaction \\ $V E G F=$ vascular endothelial growth factor
}

esophageal cancer is still not fully understood. However, there are ample data from preclinical and clinical studies demonstrating that gastroesophageal reflux disease is injurious to the esophageal mucosa.,

An animal model that is used for studying esophageal carcinogenesis is based on the rat reflux model originally proposed by Levrat and colleagues ${ }^{5}$ to study the effect of esophagitis induced after gastrectomy. This model has been extensively used, with and without carcinogens, to study various components of the refluxate..$^{6-8}$ Others have used modifications of this original model to study carcinogenesis and chemoprevention. ${ }^{9-11}$ For example, it has been shown that the reflux model does not need the carcinogen to induce esophageal tumors, ${ }^{12}$ and the pure reflux model has been used in chemopreventive studies using inhibitors of cyclooxygenase $2 .^{9,10}$ To date, there have been no attempts to confirm the malignant character of these tumors by growing them in vitro or in vivo. In addition, the exact genetic characteristics of these tumors are unclear and have not been systematically studied. The aim of the present experiment was to assess the malignant potential of cells from this model based on the ability of malignant, but not normal, cells to transform and grow in tissue culture and to examine chromosomal and genetic alterations in these tumors.

\section{Materials and Methods}

All procedures were prospectively approved by the Animal Care and Use Committee of Johns Hopkins University, and the animals received humane care in compliance with the "Guide for the care and use of laboratory animals," published by the National Research Council (National Academy Press, 1996). Animals were acclimatized in a central animal facility for 2 weeks before the experiment. Rats and mice were anesthetized with an intramuscular injection of ketamine and xylazine.

\section{Surgical Model of Reflux-induced Esophageal Tumors} Biliary reflux was induced in 10-week-old male Sprague-Dawley rats (200-250 g, Harlan). The animals were allowed 2 weeks to acclimatize and were housed at a temperature of $20^{\circ} \mathrm{C}$ to $22^{\circ} \mathrm{C}$ and a humidity of $30 \%$ to $50 \%$ at 12 -hour alternating light-dark cycle. The rats were fasted overnight but allowed water ad libitum until the operation. Briefly, the esophagus was mobilized, preserving the vagus nerves, and a loop of jejunum was then identified $4 \mathrm{~cm}$ from the ligament of Treitz. The gastroesophageal junction was divided and ligated, and an end-to-side anastomosis was constructed between the distal esophagus and jejunum (modified Levrat's model ${ }^{5}$ ). Once the animals awoke, they were allowed water ad libitum; the feeds recommenced the following day. Animals received appropriate analgesia during the perioperative and postoperative periods. The experiment concluded 9 months postoperatively.

\section{Harvesting of the Tumors}

Abdominal and thoracic viscera were exposed through a midline incision, and the tumors were assessed for size and extent. The esophagus was mobilized from the neck down to and including the esophagojejunal anastomosis. The tumors were identified and carefully dissected away from the liver and adjoining structures. The esophagus was opened longitudinally to expose the lumen; a small representative tissue was then excised from the tumor mass and preserved in $10 \%$ formalin for histologic examination. The tumors were then harvested and washed immediately with phosphate-buffered saline solution to remove any food debris and contaminants and then stored in phosphate-buffered saline at $4^{\circ} \mathrm{C}$ and transported to the laboratory for tissue culture.

\section{In Vitro Growth (Establishment of the Cell Lines)}

Tumors were mechanically minced and enzymatically digested with collagenase. The disaggregated cells were then plated in appropriate growth media as a primary culture. The culture plates were checked for the presence of cancer cells everyday. After adequate growth, single clones were picked by using a cloning ring and transferred to 96-well plates. We froze and stored aliquots of the original lineage.

\section{In Vivo Growth in Athymic Mice}

Six- to 10-week-old female CD1 null/null mice (weight, 13-16 g) were used (Charles River Company). They were kept in wire cages in a low-pathogen environment (temperature, $20^{\circ}-22^{\circ} \mathrm{C}$; humidity, 30\%-50\%; 12-hour/12-hour light-dark cycle). Autoclaved chow pellets and water were available ad libitum.

Establishment of JA, JB, AMY cell line-derived tumor specimens. Approximately $5 \times 10^{6}$ cells (with $0.1 \mathrm{~mL}$ of Matrigel [BD Biosciences] and cells in $0.1 \mathrm{~mL}$ of Hank's buffered salt solution) were injected subcutaneously into a CD1 null/null mouse. Four weeks after implantation, the resulting tumors were explanted and cut into pieces of approximately $1 \mathrm{~mm}^{3}$. These cubes were then implanted subcutaneously in the CD1 null/null mice to obtain stable tumor growth. Tumors from these animals were examined by means of routine hematoxylin and eosin staining.

Surgical orthotopic implantation of JA, JB, AMY cell linederived tumor specimens. After 1 passage, the tumor was harvested and cut into cubes of approximately 10 to $20 \mathrm{~mm}^{3}$. Tumor pieces were mixed to receive a homogeneous distribution of specimen from the center and the margin of the tumor. These pieces were subsequently implanted in 3 mice, respectively, by using microsurgical techniques. The stomach was exteriorized through a left-sided upper abdominal incision, and the serosa of the anterior wall of the forestomach (which has the similar histologic pattern as the esophagus) was removed with a scalpel. One tumor cube was sewn on the prepared gastric wall with 8-0 nonabsorbable sutures. 
The laparotomy was closed in 2 layers with 6-0 non-absorbable sutures. Animals were killed 4 weeks later.

\section{Cytogenetics}

Cells at $75 \%$ confluency were arrested in metaphase with 0.05 $\mu \mathrm{g} / \mathrm{mL}$ Colcemid (Sigma, St Louis, Mo). Ethidium bromide was added at a final concentration of $0.05 \mathrm{mg} / \mathrm{mL}$. Approximately 4 hours later, the monolayer was detached with trypsin, incubated at $37^{\circ} \mathrm{C}$ in $0.075 \mathrm{~mol} / \mathrm{L} \mathrm{KCl}$ for 10 minutes, and fixed in $3: 1$ methanol/acetic acid. Slides were prepared and G-banded by using standard techniques. At least 50 cells from each cell line were analyzed. Representative metaphases were photographed and karyotyped.

\section{Microarray Analysis, Data Normalization, and Gene Ontology Analysis of Differentially Expressed Genes} Rat $8 \mathrm{Kx} 2$ cDNA microarrays were obtained from the Johns Hopkins Cancer Center Microarray Core. They contain 8000 genes and expressed sequence tags double printed on site from a cDNA set generated by the Institute for Genomic Research. The microarray gene list is available on request. Total cellular RNA was isolated with the RNeasy RNA extraction kit (Qiagen), according to the manufacturer's protocol. Parallel experiments were performed with a common reference design, in which 3 rat cancer cell lines (JA, JB, and AMY) were compared with reference normal rat esophageal mucosal cells (Normal pooled $_{\text {; }}$ ie, a 1:1 mixture of Normal $_{1}$ :Normal). The design included a dye swap for each comparison to minimize the effects of dye bias. ${ }^{13}$ The aims of the microarray study were to identify 2-fold or greater differentially expressed genes in each cell lines relative to normal values and to examine differentially expressed genes common to all 3 dye-swap pairs to identify cancer-related genes. Statistical analysis of the microarray data was performed with GeneTraffic software (Iobion Informatics). Problematic spots were flagged for exclusion from aggregate statistical calculations and normalization based on (1) raw signal intensity to a background intensity ratio of less than 1, (2) raw signal of less than 1 times average background, and (3) raw intensity of less than 150 . Spot signals were normalized by using Lowess subgrid normalization. Differentially expressed transcripts were defined as spots with a mean $\log$ base 2 ratio absolute value of 2 or greater (ie, $\log$ base 2 ratio $\geq$ or $\leq 1$ ), and gene lists were compiled for spots meeting this criterion for each of the 3 dye-swap pairs. Final gene lists identifying differentially expressed transcripts common to all 3 dye swaps were created from the raw lists by using an intersection set operator. Onto-Express ${ }^{14}$ analysis was performed on differentially regulated gene lists to construct functional profiles by using Gene Ontology ${ }^{15}$ terms for the following categories: biological process, cellular component, and molecular function. Onto-Express calculates statistical significance values ( $P$ values) for functional categories of genes within a profile by using a hypergeometric distribution in conjunction with a false-discovery rate probability correction method to compare the observed number of genes in a given category with the entire complement of genes within that category on the array. The $P$ values distinguish between significantly overrepresented functional classes of genes and those representing random events. We focused our attention on functional categories containing at least 2 genes at a $P$ value of less than .05 .
Quantitative Reverse Transcription-Polymerase Chain Reaction for Detection of Genes of Interest

Total cellular RNA was isolated with the RNeasy RNA extraction kit (Qiagen), according to the manufacturer's protocol, and reverse transcription to cDNA was performed by using oligo dT synthesis (Invitrogen). All assays were carried out in $25-\mu \mathrm{L}$ volumes for the Smart Cycler. Rat-specific reverse transcription-polymerase chain reaction (RT-PCR) primers were obtained from Applied Biosystems by using the Assay-by-Demand platform for prefabricated TaqMan assays and amplified by using ABI's Universal master mix. Thermal cycling for the Smart Cycler was performed as follows: 1 cycle at $95^{\circ} \mathrm{C}$ for 15 minutes, followed by 45 cycles of $94^{\circ} \mathrm{C}$ for 1 second and $56^{\circ} \mathrm{C}$ for 30 seconds and extension at $76^{\circ} \mathrm{C}$ for 30 seconds. Rat phosphoglycerate kinase 1 was used as a housekeeping gene for normalization of RT-PCR data, and the 2- $\Delta \Delta \mathrm{Ct}$ method was used for calculating relative fold differential expression of candidate genes in the 3 cell lines compared with rat normal esophageal mucosal scrapings.

\section{Results \\ Histology of Reflux-associated Metaplasia and Neoplasia}

All 12 rodents had hyperplastic esophageal epithelium with several layers of esophageal epithelial cells (Figure E1, A). There was also evidence of mucosal ulceration and inflammation in the esophageal mucosa. All animals showed the presence of islands of columnar epithelium and tubular mucosal glands, with features both of mucous secretory and absorptive cells with interspersed intestinal-type goblet cells. In animals in which tumors developed, the islands of Barrett mucosa (Figure E1, B) were closely related to the lesions and sometimes formed the margin of the esophageal adenocarcinomas and adenosquamous cancers. The areas of columnar metaplasia extended upward from the anastomotic site for several millimeters. Some of the hyperplastic epithelium showed the presence of goblet cells, particularly in the basal layers. The morphological features of the jejunal mucosa were significantly distinct from those of the metaplastic epithelium. At 9 months postoperatively, 9 (75\%) of 12 rodents had esophageal tumors. Four had esophageal adenocarcinomas (Figure E1, C), 2 had squamous cell carcinomas, and 3 had adenosquamous carcinomas (Figure E1, $D)$. All of the tumors were located above the esophagojejunal anastomosis. Some of the tumors showed invasion of the submucosa (Figure E1, E). Mucin-secreting cells were obvious, even on hematoxylin and eosin stains, in the tumors with glandular differentiation (Figure E1, F).

\section{In Vitro Characteristics of Esophageal Cancer Cell Lines}

All 9 tumors were successful as primary cultures; however, only 5 could survive subsequent subculture at weekly interval. Two cell lines were found to be contaminated by Candida species and were abandoned. Finally, 3 cell lines could be established from 2 cancers, JA and JB from one cancer and AMY from another. The underlying histology of 
the primary tumor from which JA and JB cell lines were established was adenosquamous, whereas the AMY cell line was established from an adenocarcinoma. These cell lines have replicated continuously for more than 50 population doublings. We froze aliquots of the original cells at regular intervals. There has been no morphological change noticed in all 3 cell lines over this period. The cytospin histology of $\mathrm{JA}$ and JB cell lines demonstrates that they consist of well-differentiated squamous cell cancer; cytospin preparations of the AMY cell line showed some presence of mucinous cells (Figure E2).

\section{In Vivo Characteristics of Subcutaneous Implants}

Three cell lines, JA, JB, and AMY, grew subcutaneously $(n=4$ for each cell line) in either flank, and at 4 weeks after implantation, they grew to a diameter of $1.7 \pm 0.5 \mathrm{~cm}$ (JA cell line), $1.9 \pm 0.4 \mathrm{~cm}$ (JB cell line), and $1.7 \pm 0.7 \mathrm{~cm}$ (AMY cell line), respectively. All the cell lines grew differentiated squamous cell cancers (Figure E3, A).

\section{In Vivo Characteristics of Orthotopic Transplants}

All the orthotopic implants at the gastroesophageal junction grew successfully ( $\mathrm{n}=3$ per cell line) and reached greater than $1.5 \mathrm{~cm}$ in diameter in 4 weeks. The histology of these orthotopic xenografts also revealed well-differentiated squamous cell cancers for all 3 cell lines (Figure E3, $B$ ).

\section{Karyotype Analyses}

All 3 cell lines were very heterogeneous and aneuploid, with chromosome numbers in the near-tetraploid range. Chromosome gains and losses appeared to be somewhat random, although chromosomes 17 and 18 tended to be overrepresented, and chromosome 19 tended to be underrepresented. Occasional nonclonal structural changes in the chromosomes were also seen. All cell lines had lost the $\mathrm{Y}$ chromosome.

JA cell Line. This line had 2 major clones. The first had a modal chromosome number of 80 , with a chromosome 4 that had a deletion of the long arm at band q22 (Figures E4, A.1, and E5) and a translocation consisting of what appeared to be an intact chromosome 8 and the whole short arm of chromosome 17 (Figures E4, A.1, and 5, C). The second clone had a modal number of 78 and 2 translocations, the 8:17 translocation seen in the first clone and a second translocation that appeared to be an intact chromosome 7 and most of the long arm of chromosome 11 with the breakpoint in band q11 (Figures E4, A.2, and E5, B). A representative karyotype is depicted in figure $\mathrm{E} 4$, A.3.

$J B$ cell line. The JB cell line contained 2 major clones. The first had the same 8:17 translocation seen in the JA cell line (Figures E4, B.1, and E5, C), and the other had both 7:11 and 8:17 translocations observed in the JA cell line (Figures E4, B.2; E5, B; and E5, C). The modal chromosome number of both clones was 78 (Figure E4, B.3).
AMY cell line. The AMY cell line had a modal number of 80 (Figure 4, C.2) and the 7:11 translocation seen in both the JA and JB cell lines (Figures E4, C.1, and E5, B).

\section{Gene Expression Profile by Means of cDNA Microarray}

We observed that 1409 transcripts exhibited a 2-fold or greater differential expression in the JA cell line compared with the normal pooled sample (573 upregulated and 836 downregulated), the JB cell line had 1186 transcripts with 2-fold or greater differential expression (474 upregulated and 712 downregulated), and the AMY cell line had 1070 differentially expressed transcripts (390 upregulated and 680 downregulated). By using an intersection set operator, the expression of 676 transcripts was observed to be 2 -fold or greater differentially expressed in all 3 cancer cell lines relative to pooled normal squamous mucosa, including 455 downregulated and 219 upregulated transcripts (representative subset in Table E1). Using Ontogene Express, we discovered that the overexpressed transcripts had a significant overrepresentation of genes related to regulation of cell cycle, cytoskeleton rearrangements, cytokine activity, apoptosis-related events, and protein serine threonine activity (Table E2). Similarly, we discovered that the transcripts with decreased expression in response to the condition under study had a significant overrepresentation of proteolysis, metalloendopeptidase activity, glutathione S-transferase activity, extracellular matrix-related activity, and hydrolase- and zinc-binding activity. Several of these genes have shown to be of importance in the human esophageal cancers, both squamous and Barrett-associated adenocarcinomas. In compliance with the recommendations of the Microarray Gene Expression Data Society (http:// www.mged.org/), the microarray data for this study were deposited at the National Center for Biotechnology Information's Gene Expression Omnibus (http://www.ncbi.nlm. nih.gov/geo/) and are accessible through the Gene Expression Omnibus series accession number GSE1707.

\section{Quantitative RT-PCR of Genes of Interest}

We further investigated the relative expression of a subset of 5 genes of interest by means of RT-PCR in the 3 esophageal cancer cell lines versus rat normal esophageal mucosal scrapings. These genes were selected based on known roles in human esophageal cancers. ${ }^{16-20}$ The expression of vascular endothelial growth factor $(V E G F)$, polo-like kinases $(P L K)$, cyclin dependent kinase $4(C D K 4)$, hypoxiainducible factor $1 \alpha(H I F 1 \alpha)$, and insulin-like growth factor $(I G F)$ is depicted in Figure 1 and tabulated in Table E3 normalized to expression in the rat esophagus, confirming the overexpression of these transcripts in the cancer cells.

\section{Discussion}

In this study we have extensively characterized 3 cell lines derived from a reflux-associated rat model of esophageal cancer. We have shown that the cell lines are capable of 
The expression of VEGF in JA,JB and AMY
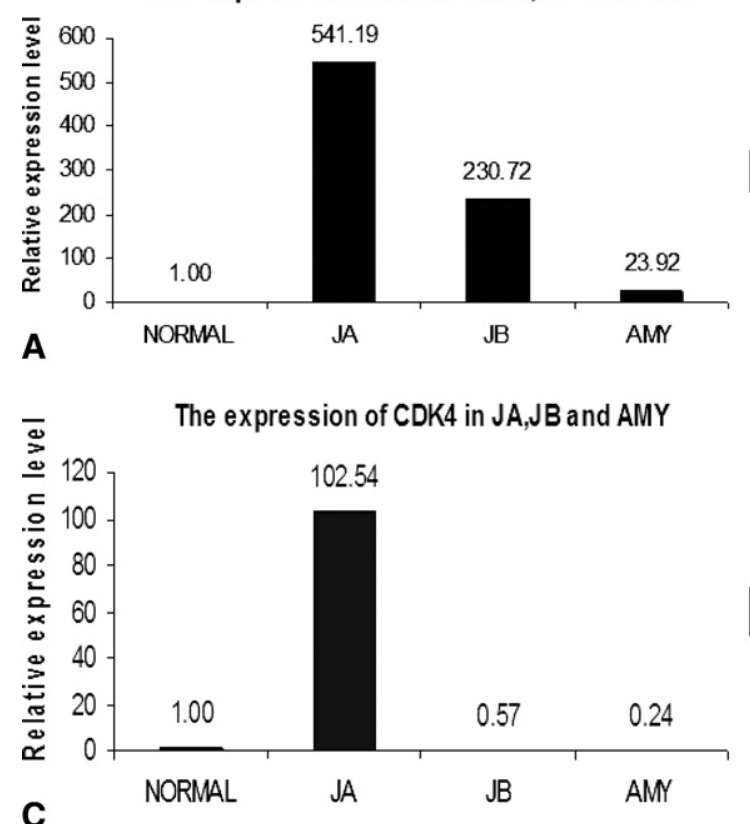

The expression of IGF in JA,JBand AMY

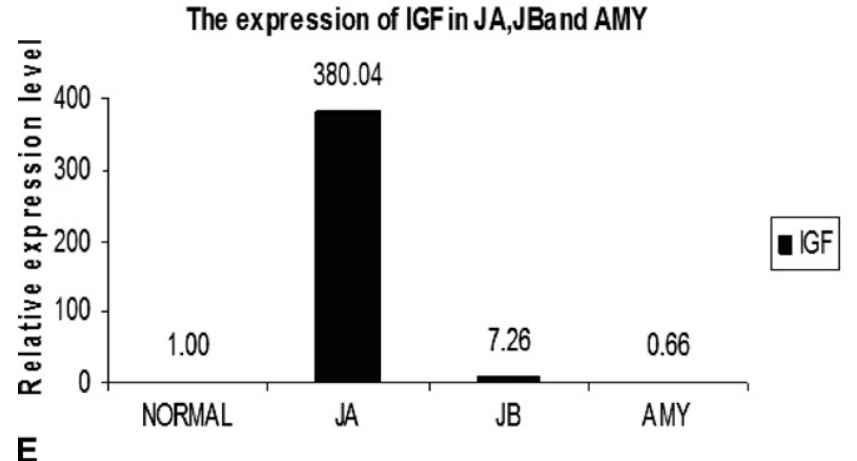

The expres sion of PLK in JA,JB and AMY
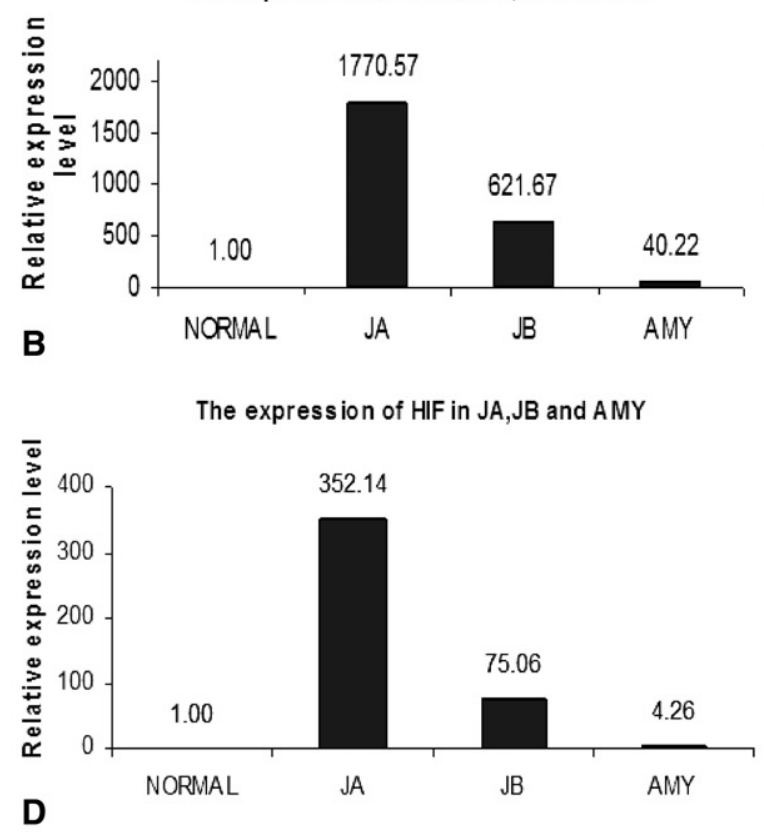

a.K

Figure 1. Results of quantitative RT-PCR reaction for genes of interest: the relative expression level compared with that seen in normal tissues. A, Vascular endothelial growth factor (VEGF) level in the JA cell line is 541 times as much as the normal level and 230 and 23 times as much as the normal level in the JB and AMY cell lines. B, The level of polo-like kinases (PLK) is 1770, 621, and 40 times that of the normal level compared with the JA, JB, and AMY cell lines. C, Normalized values of cyclin dependent kinase 4 (CDK4) in the JA, JB, and AMY cell lines. The JB and AMY cell lines did not show overexpression of this particular gene compared with that seen in normal esophageal mucosal cells. D, Expression of hypoxia-inducible factor $1 \alpha(H I F 1 \alpha)$ in the 3 cell lines compared with normal levels. E, Overexpression of insulin-like growth factor (IGF) in the JA and JB cell lines compared with that seen in the AMY line, which did not have increased expression of IGF.

propagation in vitro, as well as in vivo, in both subcutaneous and orthotopic locations, confirming their malignant potential. Furthermore, karyotype analysis confirmed highly aneuploid cell populations, with common underlying clonal translocations (eg, translocation 7:11) that likely encode for oncogenes critical in esophageal carcinogenesis. Of note, all 3 cell lines demonstrated loss of the $\mathrm{Y}$ chromosome, a genetic aberration reported to be highly frequent in both Barrett esophagus and in esophageal adenocarcinomas. ${ }^{21-23}$
Finally, the first global expression profiling of rodent esophageal cancer lines identified numerous genes that have been shown to be important in human esophageal carcinogenesis, ${ }^{24,25}$ corroborating the validity of this model.

In our study the 3 cell lines we have generated engrafted, as well differentiated, keratinizing squamous cell carcinomas, which was somewhat unexpected because the primary tumors from which these were derived had unequivocal adenocarcinomatous components. We postulate that this discrepancy is 
either an artifact of sampling caused by intratumoral heterogeneity or a result of discrepant genetic differences in the adenocarcinoma and squamous components, with the latter having a growth or survival advantage in vitro. Nevertheless, the inherent squamous nature of the cell lines is a limitation, albeit their genesis in a Barrett-like background. Another limitation of this model includes the relatively high preponderance of tumors with an adenosquamous histology that is unusual in human Barrett esophagus-associated neoplasia. We believe that reflux-initiated chronic irritation might in part be responsible for the emergence of squamous components in the rodent tumors because constant irritation is a known risk factor for development of squamous cell cancer. In addition, the native rodent esophagus contains keratinized squamous epithelium, which becomes further pronounced in reflux, and this might be another contributing factor to the higher proportion of adenosquamous lesions. At the same time, this model has numerous advantages as a proved in vivo model of metaplasia-neoplasia in the rodent esophagus, wherein $100 \%$ of animals experience Barrett-like changes at 9 months, and $75 \%$ have neoplasia. This provides a unique opportunity to study the effects of cooperating carcinogens in the onset of malignancy, and conversely, this model can serve as a platform for attempts at chemoprevention and therapy.

Despite the squamous nature of the esophageal cancer lines, these can nevertheless serve as useful in vitro models for identifying new pathways involved in esophageal carcinogenesis and for testing novel therapies. For example, we recently demonstrated 2 "drugable" pathways, the Hedgehog-signaling pathway and the epidermal growth factor receptor pathway, in the JA, JB, and AMY cell lines. ${ }^{26}$ We further investigated the efficacy of cyclopamine, a small-molecule inhibitor of the Hedgehog pathway, ${ }^{27}$ and Iressa, an inhibitor of epidermal growth factor receptor tyrosine kinase, in the 3 lines and confirmed the efficacy of these agents in esophageal cancer. These cell lines are available from the investigators for drug discovery studies for esophageal cancer, such as highthroughput combinatorial testing, and will serve as a valuable resource. Similarly, by publicly depositing the gene expression data in the National Center for Biotechnology Information's Gene Expression Omnibus (http://www.ncbi. nlm.nih.gov/geo/), accessible through the GEO series accession number GSE1707, we hope to encourage researchers to explore additional pathways important in the pathogenesis of esophageal neoplasia, including molecular targets for therapy and prevention of this disease.

In summary, we describe a rodent model of refluxinduced metaplasia and neoplasia in the esophagus, which has generated 3 new cancer cell lines capable of continuous in vitro and in vivo propagation. We present extensive molecular characterization of these lines in anticipation of their use in the preclinical study of esophageal neoplasia.

\section{References}

1. Blot WJ, Devesa SS, Kneller RW, Fraumeni JF Jr. Rising incidence of adenocarcinoma of the esophagus and gastric cardia. JAMA. 1991;265: 1287-9.

2. Lagergren J, Bergstrom R, Lindgren A, Nyren O. Symptomatic gastroesophageal reflux as a risk factor for esophageal adenocarcinoma. N Engl J Med. 1999;340:825-31.

3. Johnson LF, Harmon JW. Experimental esophagitis in a rabbit model. Clinical relevance. J Clin Gastroenterol. 1986;8(suppl 1):26-44.

4. Kauer WK, Peters JH, DeMeester TR, Ireland AP, Bremner CG, Hagen JA, editors. Mixed reflux of gastric and duodenal juices is more harmful to the esophagus than gastric juice alone. The need for surgical therapy re-emphasized. Ann Surg. 1995;222:525-31.

5. Levrat M, Lambert R, Kirshbaum G. Esophagitis produced by reflux of duodenal contents in rats. Am J Dig Dis. 1962;7:564-73.

6. Pera M, Cardesa A, Bombi JA, Ernst H, Pera C, Mohr U. Influence of esophagojejunostomy on the induction of adenocarcinoma of the distal esophagus in Sprague-Dawley rats by subcutaneous injection of 2,6dimethylnitrosomorpholine. Cancer Res. 1989;49:6803-8.

7. Chen X, Yang G, Ding WY, Bondoc F, Curtis SK, Yang CS. An esophagogastroduodenal anastomosis model for esophageal adenocarcinogenesis in rats and enhancement by iron overload. Carcinogenesis. 1999;20:1801-8.

8. Byrnes CK, Bahadursingh A, Akhter N, Parinandi NL, Natarajan V, Montgomery E, et al. Duodenal reflux produces hyperproliferative epithelial esophagitis - a possible precursor to esophageal adenocarcinoma in the rat. J Gastrointest Surg. 2003;7:172-80.

9. Oyama K, Fujimura T, Ninomiya I, Miyashita T, Kinami S, Fushida $\mathrm{S}$, et al. A COX-2 inhibitor prevents esophageal inflammationmetaplasia-adenocarcinoma sequence in rats. Carcinogenesis. 2005;26:565-70.

10. Buttar NS, Wang KK, Leontovich O, Westcott JY, Pacifico RJ, Anderson MA, et al. Chemoprevention of esophageal adenocarcinoma by COX-2 inhibitors in an animal model of Barrett's esophagus. Gastroenterology. 2002;122:1101-12.

11. Kumagai H, Mukaisho K, Sugihara H, Bamba M, Miyashita T, Miwa $\mathrm{K}$, et al. Cell kinetic study on histogenesis of Barrett's esophagus using rat reflux model. Scand J Gastroenterol. 2003;38:687-92.

12. Goldstein SR, Yang GY, Curtis SK, Reuhl KR, Liu BC, Mirvish SS, et al. Development of esophageal metaplasia and adenocarcinoma in a rat surgical model without the use of a carcinogen. Carcinogenesis. 1997; 18:2265-70.

13. Yang YH, Speed T. Design issues for cDNA microarray experiments. Nat Rev Genet. 2002;3:579-88.

14. Khatri P, Draghici S, Ostermeier GC, Krawetz SA. Profiling gene expression using Onto-Express. Genomics. 2002;79:266-70.

15. Ashburner M, Ball CA, Blake JA, Botstein D, Butler H, Cherry JM, et al. Gene ontology: tool for the unification of biology. The Gene Ontology Consortium. Nat Genet. 2000;25:25-9.

16. Lord RV, Park JM, Wickramasinghe K, DeMeester SR, Oberg S, Salonga D, et al. Vascular endothelial growth factor and basic fibroblast growth factor expression in esophageal adenocarcinoma and Barrett esophagus. J Thorac Cardiovasc Surg. 2003;125:24653.

17. Tokumitsu Y, Mori M, Tanaka S, Akazawa K, Nakano S, Niho Y Prognostic significance of polo-like kinase expression in esophageal carcinoma. Int J Oncol. 1999;15:687-92.

18. Kitahara K, Yasui W, Yokozaki H, Semba S, Hamamoto T, Hisatsugu $\mathrm{T}$, et al. Expression of cyclin D1, CDK4 and p27KIP1 is associated with the p16MTS1 gene status in human esophageal carcinoma cell lines. J Exp Ther Oncol. 1996;1:7-12.

19. Kurokawa T, Miyamoto M, Kato K, Cho Y, Kawarada Y, Hida Y, et al. Overexpression of hypoxia-inducible-factor 1alpha (HIF1alpha) in oesophageal squamous cell carcinoma correlates with lymph node metastasis and pathologic stage. Br J Cancer. 2003; 89:1042-7

20. Iravani S, Zhang HQ, Yuan ZQ, Cheng JQ, Karl RC, Jove R, et al. Modification of insulin-like growth factor 1 receptor, c-Src, and Bcl-XL protein expression during the progression of Barrett's neoplasia. Hum Pathol. 2003;34:975-82. 
21. Garewal HS, Sampliner R, Liu Y, Trent JM. Chromosomal rearrangements in Barrett's esophagus. A premalignant lesion of esophageal adenocarcinoma. Cancer Genet Cytogenet. 1989;42:281-6.

22. Beuzen F, Dubois S, Flejou JF. Chromosomal numerical aberrations are frequent in oesophageal and gastric adenocarcinomas: a study using in-situ hybridization. Histopathology. 2000;37: 241-9.

23. Hunter S, Gramlich T, Abbott K, Varma V. Y chromosome loss in esophageal carcinoma: an in situ hybridization study. Genes Chromosomes Cancer. 1993;8:172-7.

24. Kan T, Shimada Y, Sato F, Maeda M, Kawabe A, Kaganoi J, et al. Gene expression profiling in human esophageal cancers using
cDNA microarray. Biochem Biophys Res Commun. 2001;286:792801.

25. Dahlberg PS, Ferrin LF, Grindle SM, Nelson CM, Hoang CD, Jacobson B. Gene expression profiles in esophageal adenocarcinoma. Ann Thorac Surg. 2004;77:1008-15.

26. Sui G, Bonde P, Dhara S, Broor A, Wang J, Marti G, et al. Epidermal growth factor receptor and hedgehog signaling pathways are active in esophageal cancer cells from rat reflux model. $J$ Surg Res. 2006;134:1-9.

27. Berman DM, Karhadkar SS, Maitra A, Montes De Oca R, Gerstenblith MR, Briggs K, et al. Widespread requirement for Hedgehog ligand stimulation in growth of digestive tract tumours. Nature. 2003;425:846-51. 

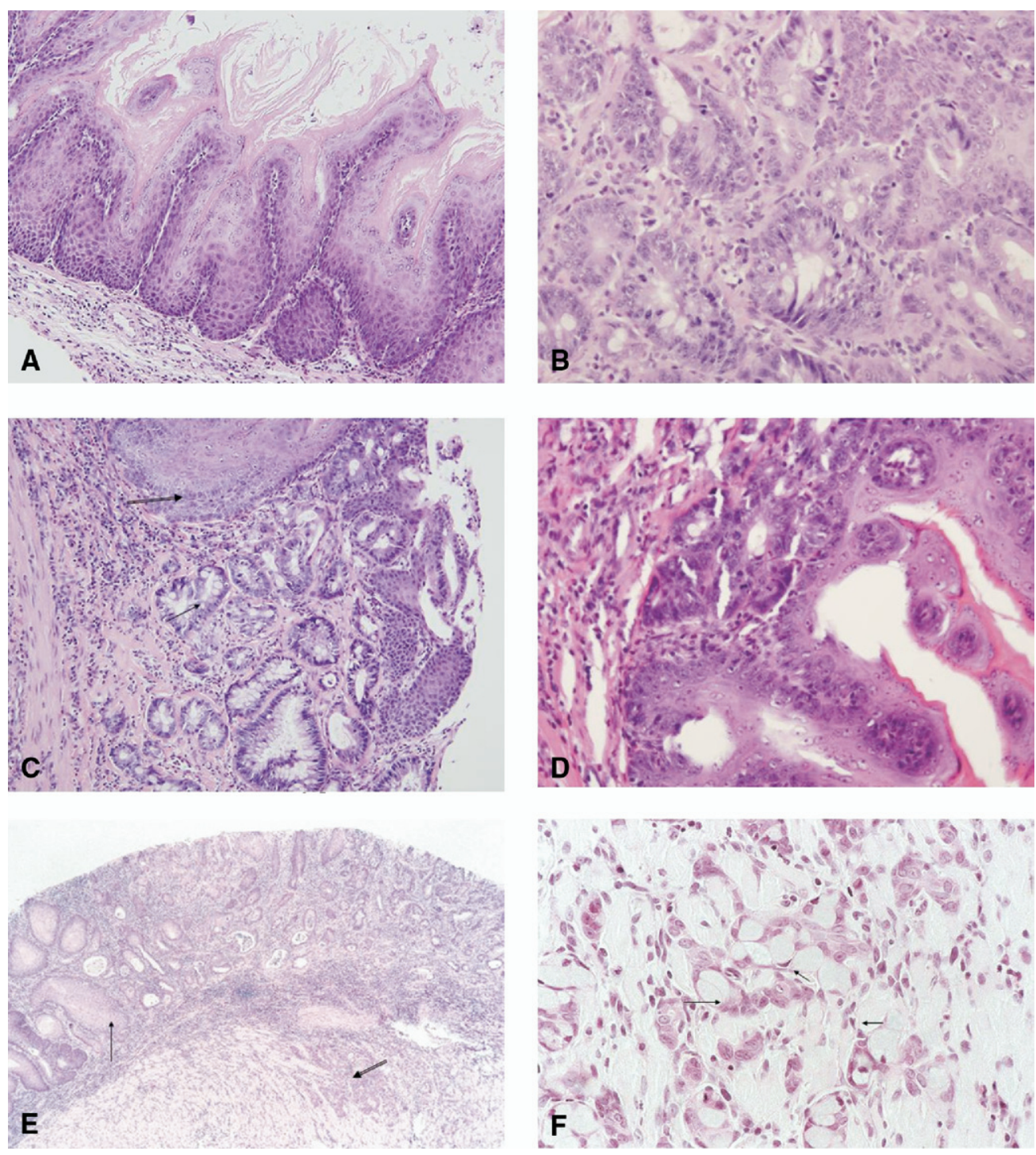

Figure E1. Reflux-induced tumor histology. A, Multilayered epithelium: a representative high-magnification photomicrograph of the esophageal mucosa subjected to surgically induced biliary reflux showing multilayered epithelium in the rat esophagus. B, Barrett esophagus: a high-magnification photomicrograph of the columnar metaplasia. C, Adenocarcinoma: remnants of squamous epithelium adjoining the adenocarcinomatous lesion in the rat esophagus. The double arrow shows squamous esophageal mucosa, and the single arrow shows adenocarcinoma. D, Adenosquamous cancer: a typical adenosquamous lesion is shown that is common in a surgically induced biliary rat reflux model. E, Invasive adenocarcinoma: submucosal extension of adenocarcinoma (double arrow) is depicted adjoining the normal squamous epithelium (single arrow). F, Adenocarcinoma (high magnification): a high-magnification photomicrograph showing mucin-producing cells (arrows) in the adenocarcinoma of the esophagus of reflux-induced tumor. 


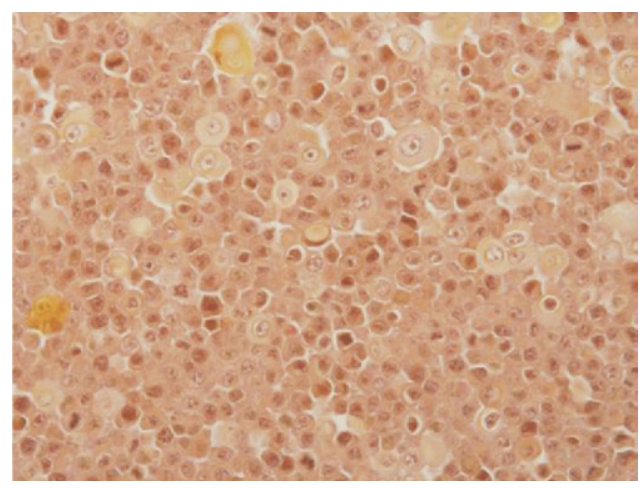

Figure E2. Cell line histology. A high-magnification cell cytospin preparation of the AMY cell line showing few interspersed mucin-producing cells.
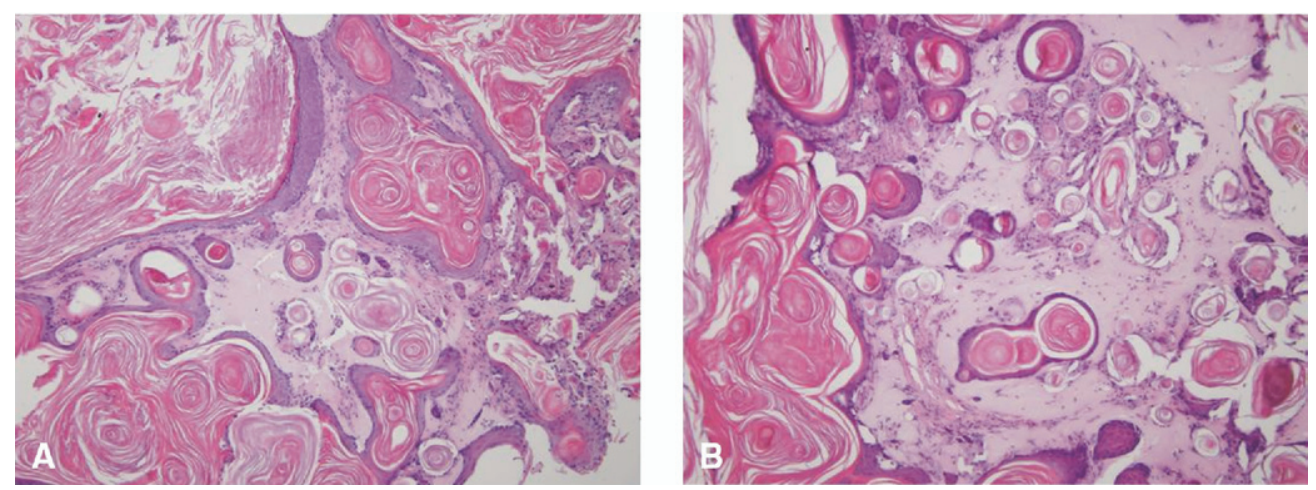

Figure E3. Xenograft histology. A, A well-differentiated squamous cell cancer from the subcutaneous implant specimen. B, A similar high-magnification photomicrograph showing epithelial pearls and squamous cell cancer features of one of the orthotopic transplanted tumors. 

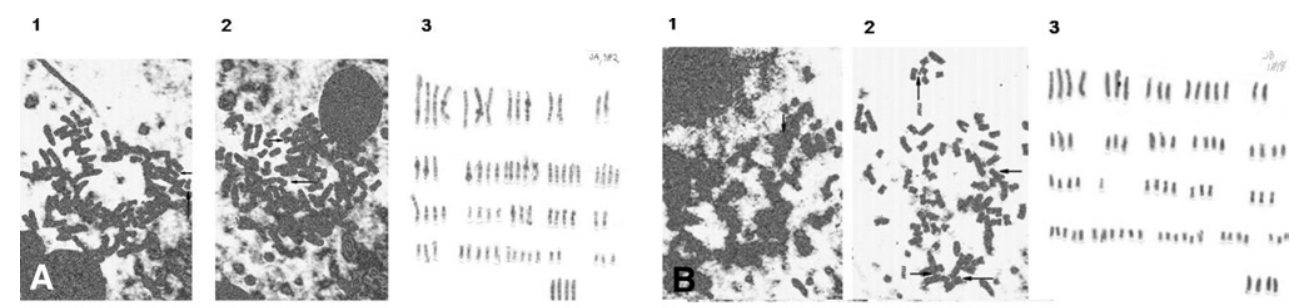

$$
1
$$

2

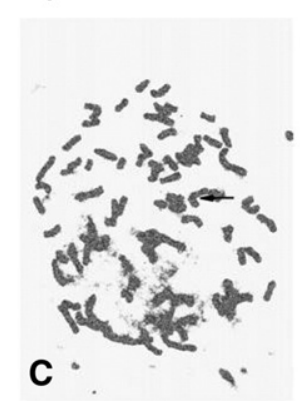

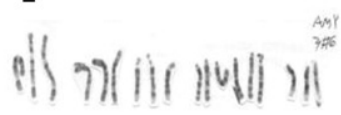

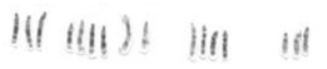

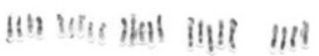

II) IIt eirn I i, it

IIII

Figure E4. A, The JA cell line had 2 major clones, one with a modal number of 80 and the other with a modal number of 78. A.1, Metaphase from first clone showing a deletion of chromosome 4 at band q22 (large arrow) and the unbalanced 8:17 translocation (small arrow). A.2, Metaphase from second clone showing an unbalanced 7:11 translocation (long arrow) and the unbalanced 8:17 translocation (short arrow). A.3, Typical karyotype, with chromosomes 17 and 18 being overrepresented. B, The JB cell line had 2 major clones with a modal chromosomal number of 78. B.1, Metaphase from first clone showing the unbalanced 8:17 translocation. B.2, Metaphase from the second clone showing the unbalanced 7:11 translocation (long arrow) and the unbalanced 8:17 translocation (short arrow). Two small marker chromosomes (mar) were often, but not always, seen in both clones. B.3, Representative karyotype from the JB cell line. C, The AMY cell line had the 7:11 translocation seen in JA and JB cell lines (C.1, arrow) and was a single clone with a modal chromosomal number of 80 (C.2). 


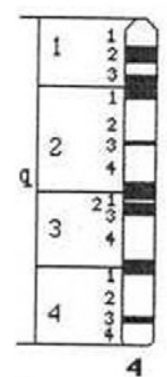

A

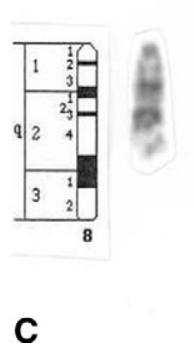

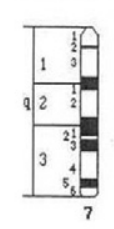

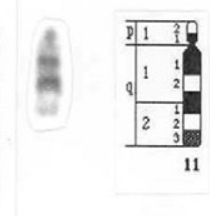

B

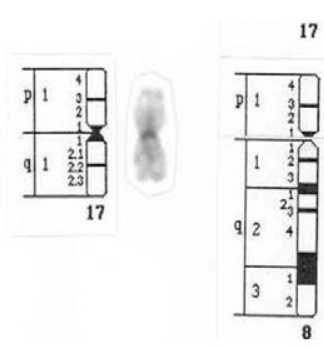

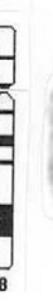
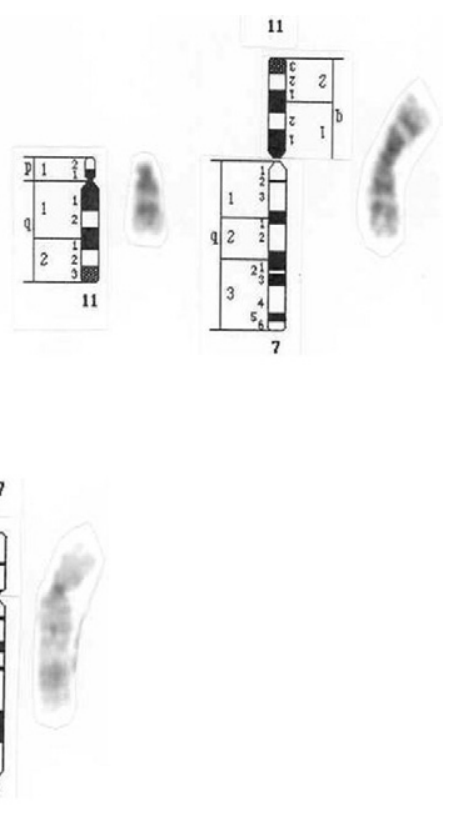

Figure E5. A, Ideogram of chromosome 4 showing deletion at band q22. B, Ideogram showing the unbalanced 7:11 translocation. C, Ideogram showing the unbalanced 8:17 translocation. 
TABLE E1. Representative differentially expressed genes common to all 3 cell lines compared with normal esophageal epithelium

\begin{tabular}{|c|c|c|}
\hline Gene ID & Name & GenBank accession no. \\
\hline RGICI01 & 2,3-Bisphosphoglycerate mutase & ВC062240 \\
\hline RGIFD90 & Actin-related protein $2 / 3$ complex, subunit $1 B$ & NM_019289 \\
\hline RGIBC32 & Acyl-coenzyme A: cholesterol acyltransferase & $\mathrm{D} 86373$ \\
\hline RGIZB40 & ADP-ribosylation-like 3 & B0204995 \\
\hline RGIAA10 & $\begin{array}{l}\text { Aldehyde reductase } 1 \text { (low Km aldose reductase) (5.8 kb Pst I } \\
\text { fragment, probably the functional gene) }\end{array}$ & ВС062034 \\
\hline UI-R-C2-ms-b-07-0-UI & Bone morphogenetic protein 6 & AY184240 \\
\hline RGICC80 & Cadherin 3, type 1, P-cadherin (placental) & XM_226426 \\
\hline RGICV80 & Carboxyl ester lipase & X16054 \\
\hline RGICV07 & Caspase 3 & BF408215 \\
\hline RGIAC47 & Cyclin-dependent kinase 4 & ВС063158 \\
\hline RGIAM32 & Follistatin & BF389575 \\
\hline RGIAD15 & Glutathione reductase & U73174 \\
\hline RGIDR30 & Glutathione synthetase & L38615 \\
\hline RGIAE95 & Glyceraldehyde-3-phosphate dehydrogenase & AF106860 \\
\hline RGIAJ39 & Growth factor-binding protein 1 & AF142758 \\
\hline RGIAN82 & $\mathrm{H} 2 \mathrm{~A}$ histone family, member $\mathrm{Z}$ & B0201156 \\
\hline RGICS51 & High-mobility group box 2 & BG380210 \\
\hline RGIBD80 & Hypoxia-inducible factor $1, \alpha$ subunit & AF057308 \\
\hline RGICD34 & Insulin-like growth factor 2 receptor & U59809 \\
\hline RGIAA38 & Lactate dehydrogenase $\mathrm{A}$ & X01964 \\
\hline RGIEB96 & Low-affinity Na-dependent glucose transporter (SGLT2) & U29881 \\
\hline RGIAC88 & Polo-like kinase homolog (Drosophila) & U10188 \\
\hline RGIBW70 & Polypyrimidine tract binding protein & BC061858 \\
\hline RGIFD46 & Preproenkephalin, related sequence & BE111086 \\
\hline RGIAS16 & Profilin & $\mathrm{BI} 282907$ \\
\hline RGIAV34 & Programmed cell death 8 (apoptosis-inducing factor) & AB041723 \\
\hline RGIAG94 & RAN, member RAS oncogene family & BM384578 \\
\hline RGIFD16 & S-adenosylhomocysteine hydrolase & ВС061841 \\
\hline RGIBZ01 & Sepiapterin reductase & XM_342714 \\
\hline RGIAE15 & Serine/threonine kinase 16 & D86220 \\
\hline RGIAW68 & $\begin{array}{l}\text { Similar to high-mobility group protein } 1 \text { (HMG-1) (Amphoterin) } \\
\text { (heparin-binding protein p30) (LOC297927), mRNA }\end{array}$ & B0198991 \\
\hline RGIBK38 & Similar to Kruppel-like factor 7 (ubiquitous) (LOC363243), mRNA & BE112585 \\
\hline RGIBK44 & Solute carrier family 1 , member 3 & NM_019225 \\
\hline RGIAH55 & Solute carrier family 12 , member 2 & AF051561 \\
\hline RGIDZ81 & Solute carrier family 2, member 5 & D13871 \\
\hline RGIBC25 & Thymic stromal-derived lymphopoietin, receptor & NM_134465 \\
\hline RGIAB90 & Thymosin, $\beta 10$ & BE117292 \\
\hline RGIDV78 & Thyroid hormone-response protein 1 & BE118252 \\
\hline
\end{tabular}


TABLE E1. Continued

\begin{tabular}{|c|c|c|}
\hline Gene ID & Name & GenBank accession no. \\
\hline RGIEA66 & Transketolase & BM384351 \\
\hline RGICK91 & Vascular endothelial growth factor & BE098396 \\
\hline RGIBY29 & Wingless-type MMTV integration site family, member 4 & AF188608 \\
\hline RGIAH24 & Zinc finger protein 36 & NM_133290 \\
\hline
\end{tabular}

$A D P$, Adenosine diphosphate; ATPase, adenosine triphosphatase. 
TABLE E2. Functional categories significantly overrepresented in the differentially regulated gene sets

\begin{tabular}{|c|c|c|c|c|c|c|}
\hline \multicolumn{7}{|c|}{ A. Functional categories significantly downregulated in all 3 cancer cell lines } \\
\hline $\begin{array}{l}\text { GO functional } \\
\text { category }\end{array}$ & GO ID & Gene category & $P$ value & Gene name & $\begin{array}{c}\text { GenBank } \\
\text { accession no. }\end{array}$ & $\begin{array}{l}\text { UniGene } \\
\text { ID }\end{array}$ \\
\hline Molecular function & & & & $\begin{array}{l}\text { Proprotein convertase } \\
\text { subtilisin/kexin type } 7\end{array}$ & U36580 & Rn. 10653 \\
\hline \multirow[t]{6}{*}{ Biological process } & G0:0006508 & Proteolysis and & .001873 & Subtilisin-like endoprotease & L31894 & Rn. 950 \\
\hline & & & & Insulin-degrading enzyme & X67269 & Rn. 45029 \\
\hline & & & & Cathepsin K & NM_031560 & Rn. 5598 \\
\hline & & & & Cathepsin E & BC06-2002 & Rn. 92738 \\
\hline & & & & Cathepsin L & ВС063175 & Rn. 1294 \\
\hline & & & & $\mathrm{N}$-arginine dibasic convertase 1 & NM_012993 & Rn. 2081 \\
\hline Molecular function & & & & $\begin{array}{l}\text { Matrix metalloproteinase } 2 \text { (72- } \\
\text { kd type IV collagenase) }\end{array}$ & $\mathrm{X71466}$ & Rn. 6422 \\
\hline \multirow[t]{2}{*}{ Molecular function } & G0:0004364 & $\begin{array}{l}\text { Glutathione transferase } \\
\text { activity }\end{array}$ & .002243 & $\begin{array}{l}\text { Glutathione-S-transferase, } \mu \\
\text { type } 3(\mathrm{Yb} 3)\end{array}$ & ВС059130 & Rn. 6036 \\
\hline & & & & Glutathione-S-transferase, $\mu 2$ & $\mathrm{BI} 302435$ & Rn. 625 \\
\hline \multirow[t]{2}{*}{ Molecular function } & G0:0005201 & Extracellular matrix & .0023 & Elastin & M60647 & Rn. 54384 \\
\hline & & structural constituent & & Procollagen, type I, $\alpha 2$ & AF121217 & Rn. 107239 \\
\hline \multirow[t]{2}{*}{ Biological process } & G0:0006730 & One-carbon compound & .003204 & Dihydrofolate reductase & BF406309 & Rn. 24681 \\
\hline & & metabolism & & Carbonic anhydrase 3 & NM_019292 & Rn. 1647 \\
\hline \multirow[t]{2}{*}{ Molecular function } & G0:0004252 & Serine-type & .004305 & Subtilisin-like endoprotease & L31894 & Rn. 950 \\
\hline & & endopeptidase activity & & $\begin{array}{l}\text { Proprotein convertase } \\
\text { subtilisin/kexin type } 7\end{array}$ & U36580 & Rn. 10653 \\
\hline \multirow{13}{*}{ Cellular component } & & & & Clusterin & M16975 & Rn. 1780 \\
\hline & & & & Cathepsin L & ВС063175 & Rn. 1294 \\
\hline & & & & Cathepsin K & NM_031560 & Rn. 5598 \\
\hline & & & & $\begin{array}{l}\text { ATP-binding cassette, subfamily } \\
\text { D (ALD), member } 3\end{array}$ & D90038 & Rn. 7024 \\
\hline & & & & Albumin & V01222 & Rn. 34353 \\
\hline & & & & $\begin{array}{l}\text { Secreted acidic cysteine-rich } \\
\text { glycoprotein }\end{array}$ & BM384341 & Rn. 98989 \\
\hline & & & & $\begin{array}{l}\text { Kinase insert domain protein } \\
\text { receptor }\end{array}$ & U93306 & Rn. 88869 \\
\hline & & & & $\begin{array}{l}\text { Superoxide dismutase } 3, \\
\text { extracellular }\end{array}$ & Z24721 & Rn. 10358 \\
\hline & & & & $\begin{array}{l}\text { Secretoglobin, family } 1 \mathrm{~A}, \\
\text { member } 1 \text { (uteroglobin) }\end{array}$ & Al009524 & Rn. 2206 \\
\hline & & & & Aquaporin 1 & X67948 & Rn. 1618 \\
\hline & & & & $\begin{array}{l}\text { Branched chain } \\
\text { aminotransferase 2, } \\
\text { mitochondrial }\end{array}$ & ВС061790 & Rn. 981 \\
\hline & & & & CD24 antigen & ВС064439 & Rn. 6007 \\
\hline & & & & Matrix Gla protein & ВM384331 & Rn. 2379 \\
\hline
\end{tabular}


TABLE E2. Continued

\begin{tabular}{|c|c|c|c|c|c|c|}
\hline \multicolumn{7}{|c|}{ A. Functional categories significantly downregulated in all 3 cancer cell lines } \\
\hline $\begin{array}{l}\text { GO functional } \\
\text { category }\end{array}$ & GO ID & Gene category & $P$ value & Gene name & $\begin{array}{c}\text { GenBank } \\
\text { accession no. }\end{array}$ & $\begin{array}{l}\text { UniGene } \\
\text { ID }\end{array}$ \\
\hline \multirow[t]{2}{*}{ Molecular function } & G0:0004842 & Ubiquitin-protein ligase & .008121 & Progestin-induced protein & X64411 & Rn. 54812 \\
\hline & & activity & & $\begin{array}{l}\text { Ubiquitin-conjugating enzyme } \\
\text { E2D } 2\end{array}$ & BE115845 & Rn. 7390 \\
\hline \multirow[t]{6}{*}{ Cellular component } & G0:0005578 & Extracellular matrix & .010148 & $\begin{array}{l}\text { Secreted acidic cysteine-rich } \\
\text { glycoprotein }\end{array}$ & BM384341 & Rn. 98989 \\
\hline & & & & Elastin & M60647 & Rn. 54384 \\
\hline & & & & Extracellular matrix protein 1 & XM_215645 & Rn. 97792 \\
\hline & & & & Procollagen, type I, $\alpha 2$ & AF121217 & Rn. 107239 \\
\hline & & & & Glypican 3 & M22400 & Rn. 9717 \\
\hline & & & & $\begin{array}{l}\text { Matrix metalloproteinase } 2 \\
\text { (72-kd type IV collagenase) }\end{array}$ & X71466 & Rn. 6422 \\
\hline \multirow[t]{2}{*}{ Molecular function } & G0:0008483 & Transaminase activity & .024083 & $\begin{array}{l}\text { Branched chain } \\
\text { aminotransferase 2, } \\
\text { mitochondrial }\end{array}$ & ВС061790 & Rn. 981 \\
\hline & & & & Aminolevulinic acid synthase 1 & NM_024484 & Rn. 97126 \\
\hline \multirow[t]{2}{*}{ Molecular function } & G0:0019838 & Growth factor binding & .024465 & $\begin{array}{l}\text { Insulin-like growth factor- } \\
\text { binding protein } 5\end{array}$ & AF139830 & Rn. 1593 \\
\hline & & & & $\begin{array}{l}\text { Insulin-like growth factor- } \\
\text { binding protein } 6\end{array}$ & B0204169 & Rn. 6431 \\
\hline \multirow[t]{3}{*}{ Molecular function } & G0:0008270 & Zinc ion binding & .029383 & $\begin{array}{l}\text { Solute carrier family } 11 \text {, } \\
\text { member } 2\end{array}$ & AF008439 & Rn. 11418 \\
\hline & & & & Carbonic anhydrase 3 & NM_019292 & Rn. 1647 \\
\hline & & & & $\begin{array}{l}\text { Matrix metalloproteinase } 2 \text { (72- } \\
\text { kd type IV collagenase) }\end{array}$ & X71466 & Rn. 6422 \\
\hline \multirow[t]{13}{*}{ Molecular function } & G0:0016787 & Hydrolase activity & .030582 & Acid phosphatase, prostate & M32397 & Rn. 40121 \\
\hline & & & & Reelin & NM_080394 & Rn. 98353 \\
\hline & & & & $\mathrm{N}$-arginine dibasic convertase 1 & NM_012993 & Rn. 2081 \\
\hline & & & & $\begin{array}{l}\text { Matrix metalloproteinase } 2 \text { (72- } \\
\text { kd type IV collagenase) }\end{array}$ & X71466 & Rn. 6422 \\
\hline & & & & Cathepsin K & NM_031560 & Rn. 5598 \\
\hline & & & & Insulin-degrading enzyme & $X 67269$ & Rn. 45029 \\
\hline & & & & Cathepsin E & BC062002 & Rn. 92738 \\
\hline & & & & Cathepsin L & ВС063175 & Rn. 1294 \\
\hline & & & & $\begin{array}{l}\text { Nudix (nucleoside diphosphate- } \\
\text { linked moiety X)-type motif } 6\end{array}$ & U58289 & Rn. 83600 \\
\hline & & & & $\begin{array}{l}\text { Proprotein convertase } \\
\text { subtilisin/kexin type } 7\end{array}$ & U36580 & Rn. 10653 \\
\hline & & & & Dynamin 1 & X54531 & Rn. 10354 \\
\hline & & & & $\begin{array}{l}\text { Adenosine monophosphate } \\
\text { deaminase } 3\end{array}$ & U90888 & Rn. 11106 \\
\hline & & & & Subtilisin-like endoprotease & L31894 & Rn. 950 \\
\hline \multirow[t]{3}{*}{ Molecular function } & G0:0008237 & Metallopeptidase & .031231 & Insulin-degrading enzyme & X67269 & Rn. 45029 \\
\hline & & activity & & $\mathrm{N}$-arginine dibasic convertase 1 & NM_012993 & Rn. 2081 \\
\hline & & & & $\begin{array}{l}\text { Matrix metalloproteinase } 2 \text { (72- } \\
\text { kd type IV collagenase) }\end{array}$ & X71466 & Rn. 6422 \\
\hline \multirow[t]{2}{*}{ Molecular function } & G0:0005520 & $\begin{array}{l}\text { Insulin-like growth } \\
\text { factor binding }\end{array}$ & .038283 & $\begin{array}{l}\text { Insulin-like growth factor- } \\
\text { binding protein } 5\end{array}$ & AF139830 & Rn. 1593 \\
\hline & & & & $\begin{array}{l}\text { Insulin-like growth factor- } \\
\text { binding protein } 6\end{array}$ & B0204169 & Rn. 6431 \\
\hline \multirow[t]{3}{*}{ Cellular component } & G0:0005576 & Extracellular & .040352 & Acid phosphatase, prostate & M32397 & Rn. 40121 \\
\hline & & & & Insulin-like growth factor 2 & X14834 & Rn. 964 \\
\hline & & & & $\begin{array}{l}\text { Insulin-like growth factor- } \\
\text { binding protein } 5\end{array}$ & AF139830 & Rn. 1593 \\
\hline
\end{tabular}


Table E2. Continued

\begin{tabular}{|c|c|c|c|c|c|c|}
\hline \multicolumn{7}{|c|}{ A. Functional categories significantly downregulated in all 3 cancer cell lines } \\
\hline \multirow[t]{4}{*}{$\begin{array}{l}\text { GO functional } \\
\text { category }\end{array}$} & GO ID & Gene category & $P$ value & Gene name & $\begin{array}{c}\text { GenBank } \\
\text { accession no. }\end{array}$ & $\begin{array}{l}\text { UniGene } \\
\text { ID }\end{array}$ \\
\hline & & & & Extracellular matrix protein 1 & XM_215645 & Rn. 97792 \\
\hline & & & & Matrix Gla protein & BM384331 & Rn. 2379 \\
\hline & & & & $\begin{array}{l}\text { Insulin-like growth factor- } \\
\text { binding protein } 6\end{array}$ & B0204169 & Rn. 6431 \\
\hline \multirow[t]{2}{*}{ Molecular function } & G0:0004197 & Cysteine-type & .050041 & Cathepsin K & NM_031560 & Rn. 5598 \\
\hline & & endopeptidase activity & & Cathepsin L & ВС063175 & Rn. 1294 \\
\hline \multicolumn{7}{|c|}{ B. Functional categories significantly upregulated in all $\mathbf{3}$ cancer cell lines } \\
\hline $\begin{array}{l}\text { GO functional } \\
\text { category }\end{array}$ & GO ID & Gene category & $P$ value & Gene name & $\begin{array}{c}\text { GenBank } \\
\text { accession no. }\end{array}$ & $\begin{array}{l}\text { UniGene } \\
\text { ID }\end{array}$ \\
\hline \multirow[t]{2}{*}{ Cellular component } & G0:0005694 & Chromosome & $2.67 \mathrm{E}-12$ & High-mobility group box 2 & BG380210 & Rn. 2874 \\
\hline & & & & $\mathrm{H} 2 \mathrm{~A}$ histone family, member Z & B0201156 & Rn. 112573 \\
\hline \multirow[t]{2}{*}{ Biological process } & G0:0007286 & Spermatid development & $1.92 \mathrm{E}-04$ & Thymosin, $\beta 10$ & BE117292 & Rn. 5983 \\
\hline & & & & $\begin{array}{l}\text { RAN, member RAS oncogene } \\
\text { family }\end{array}$ & BM384578 & Rn. 107698 \\
\hline \multirow[t]{2}{*}{ Molecular function } & G0:0006330 & $\begin{array}{l}\text { Single-stranded DNA } \\
\text { binding }\end{array}$ & .001618 & $\begin{array}{l}\text { Nuclear ubiquitous casein } \\
\text { kinase and cyclin-dependent } \\
\text { kinase substrate }\end{array}$ & NM_022799 & Rn. 21324 \\
\hline & & & & $\begin{array}{l}\text { Polypyrimidine tract-binding } \\
\text { protein } 1\end{array}$ & ВС061858 & Rn. 64440 \\
\hline \multirow[t]{2}{*}{ Biological process } & G0:0030036 & Actin cytoskeleton & .003425 & Thymosin, $\beta 10$ & BE117292 & Rn. 5983 \\
\hline & & $\begin{array}{l}\text { organization and } \\
\text { biogenesis }\end{array}$ & & Profilin 1 & $\mathrm{BI} 282907$ & Rn. 1152 \\
\hline \multirow[t]{4}{*}{ Biological process } & G0:0000074 & Regulation of cell cycle & .004719 & Cyclin-dependent kinase 4 & ВС063158 & Rn. 6115 \\
\hline & & & & $\begin{array}{l}\text { RAN, member RAS oncogene } \\
\text { family }\end{array}$ & BM384578 & Rn. 107698 \\
\hline & & & & $\begin{array}{l}\text { Nuclear ubiquitous casein } \\
\text { kinase and cyclin-dependent } \\
\text { kinase substrate }\end{array}$ & NM_022799 & Rn. 21324 \\
\hline & & & & Cell-cycle protein p55CDC & NM_171993 & Rn. 9262 \\
\hline \multirow[t]{2}{*}{ Molecular function } & G0:0003690 & $\begin{array}{l}\text { Double-stranded DNA } \\
\text { binding }\end{array}$ & .005205 & $\begin{array}{l}\text { Nuclear ubiquitous casein } \\
\text { kinase and cyclin-dependent } \\
\text { kinase substrate }\end{array}$ & NM_022799 & Rn. 21324 \\
\hline & & & & High-mobility group box 2 & BG380210 & Rn. 2874 \\
\hline \multirow[t]{2}{*}{ Molecular function } & G0:0008415 & Acyltransferase activity & .010213 & $\begin{array}{l}\text { Spermidine/spermine N1-acetyl } \\
\text { transferase }\end{array}$ & ВС060588 & Rn. 107986 \\
\hline & & & & $\begin{array}{l}\text { Acyl-coenzyme A: cholesterol } \\
\text { acyltransferase }\end{array}$ & D86373 & Rn. 59 \\
\hline \multirow[t]{2}{*}{ Biological process } & G0:0006096 & Glycolysis & .010961 & $\begin{array}{l}\text { Glyceraldehyde-3-phosphate } \\
\text { dehydrogenase }\end{array}$ & AF106860 & Rn. 91450 \\
\hline & & & & Lactate dehydrogenase A & X01964 & Rn. 107896 \\
\hline \multirow[t]{2}{*}{ Molecular function } & G0:0003676 & Nucleic acid binding & .013416 & $\begin{array}{l}\text { Polypyrimidine tract-binding } \\
\text { protein } 1\end{array}$ & ВС061858 & Rn. 64440 \\
\hline & & & & Zinc finger protein 36 & NM_133290 & Rn. 82737 \\
\hline \multirow[t]{3}{*}{ Biological process } & G0:0007264 & $\begin{array}{l}\text { Small GTPase-mediated } \\
\text { signal transduction }\end{array}$ & .017968 & $\begin{array}{l}\text { RAN, member RAS oncogene } \\
\text { family }\end{array}$ & BM384578 & Rn. 107698 \\
\hline & & & & $\begin{array}{l}\text { P21 (CDKN1A)-activated kinase } \\
\quad 1\end{array}$ & U49953 & Rn. 9149 \\
\hline & & & & ADP-ribosylation factor-like 3 & B0204995 & Rn. 9538 \\
\hline \multirow[t]{2}{*}{ Molecular function } & G0:0005125 & Cytokine activity & .020391 & $\begin{array}{l}\text { Thymic stromal-derived } \\
\text { lymphopoietin, receptor }\end{array}$ & NM_134465 & Rn. 22704 \\
\hline & & & & Bone morphogenetic protein 6 & AY184240 & Rn. 40476 \\
\hline
\end{tabular}


TABLE E2. Continued

\begin{tabular}{|c|c|c|c|c|c|c|}
\hline \multicolumn{7}{|c|}{ B. Functional categories significantly upregulated in all 3 cancer cell lines } \\
\hline $\begin{array}{l}\text { GO functional } \\
\text { category }\end{array}$ & GO ID & Gene category & $P$ value & Gene name & $\begin{array}{c}\text { GenBank } \\
\text { accession no. }\end{array}$ & $\begin{array}{l}\text { UniGene } \\
\text { ID }\end{array}$ \\
\hline \multirow[t]{9}{*}{ Cellular component } & G0:0005634 & Nucleus & .027878 & $\begin{array}{l}\text { Programmed cell death } 8 \\
\text { (apoptosis-inducing factor) }\end{array}$ & AB041723 & Rn. 8124 \\
\hline & & & & $\mathrm{H} 2 \mathrm{~A}$ histone family, member $\mathrm{Z}$ & B0201156 & Rn. 112573 \\
\hline & & & & $\begin{array}{l}\text { Polypyrimidine tract-binding } \\
\text { protein } 1\end{array}$ & ВC061858 & Rn. 64440 \\
\hline & & & & $\begin{array}{l}\text { Nuclear ubiquitous casein } \\
\text { kinase and cyclin-dependent } \\
\text { kinase substrate }\end{array}$ & NM_022799 & Rn. 21324 \\
\hline & & & & Polo-like kinase 1 (Drosophila) & U10188 & Rn. 11034 \\
\hline & & & & Zinc finger protein 36 & NM_133290 & Rn. 82737 \\
\hline & & & & $\begin{array}{l}\text { RAN, member RAS oncogene } \\
\text { family }\end{array}$ & BM384578 & Rn. 107698 \\
\hline & & & & $\begin{array}{l}\text { Hypoxia-inducible factor } 1, \alpha \\
\text { subunit }\end{array}$ & AF057308 & Rn. 10852 \\
\hline & & & & High-mobility group box 2 & BG380210 & Rn. 2874 \\
\hline \multirow[t]{2}{*}{ Biological process } & G0:0007049 & Cell cycle & .032999 & Cyclin-dependent kinase 4 & ВС063158 & Rn. 6115 \\
\hline & & & & Polo-like kinase 1 (Drosophila) & U10188 & Rn. 11034 \\
\hline \multirow[t]{2}{*}{ Molecular function } & G0:0005516 & Calmodulin binding & .034449 & $\begin{array}{l}\text { Brain-abundant, membrane- } \\
\text { attached signal protein } 1\end{array}$ & BE110763 & Rn. 37779 \\
\hline & & & & Calponin 3 , acidic & ВС062020 & Rn. 57635 \\
\hline \multirow[t]{2}{*}{ Molecular function } & G0:0004691 & cAMP-dependent & .035111 & Cyclin-dependent kinase 4 & ВС063158 & Rn. 6115 \\
\hline & & protein kinase activity & & Serine/threonine kinase 16 & $\mathrm{D} 86220$ & Rn. 13308 \\
\hline \multirow[t]{2}{*}{ Molecular function } & G0:0004682 & Protein kinase CK2 & .039394 & Cyclin-dependent kinase 4 & ВС063158 & Rn. 6115 \\
\hline & & activity & & Serine/threonine kinase 16 & D86220 & Rn. 13308 \\
\hline \multirow[t]{3}{*}{ Cellular component } & G0:0005856 & Cytoskeleton & .04869 & Thymosin, $\beta 10$ & BE117292 & Rn. $\quad 5983$ \\
\hline & & & & Profilin 1 & BI282907 & 1152 \\
\hline & & & & Moesin & AF004811 & 2762 \\
\hline \multirow[t]{4}{*}{ Molecular function } & G0:0004674 & Protein serine/threonine & .049573 & Cyclin-dependent kinase 4 & ВС063158 & Rn. $\quad 6115$ \\
\hline & & kinase activity & & $\begin{array}{l}\text { P21 (CDKN1A)-activated kinase } \\
\quad 1\end{array}$ & U49953 & Rn. $\quad 9149$ \\
\hline & & & & Polo-like kinase 1 (Drosophila) & U10188 & Rn. 11034 \\
\hline & & & & Serine/threonine kinase 16 & D86220 & Rn. 13308 \\
\hline
\end{tabular}

Onto-Express (OE) analysis of the differentially regulated gene lists uses Gene Ontology (GO) terms to identify functional categories significantly overrepresented within the downregulated $(A)$ or upregulated $(B)$ gene sets. $\mathrm{OE}$ also computes accompanying significance values $(P$ values) by comparing the observed number of genes in a given category with the total number of genes within that category on the array. We focused our attention on those functional categories containing at least 2 genes at a $P$ value of less than .05 . Genes can be associated with more than $1 \mathrm{GO}$ term. ATP, Adenosine triphosphate; GTPase, glutathione triphosphatase; $A D P$, adenosine diphosphate; $c A M P$, cyclic adenosine monophosphate.

TABLE E3. Results of quantitative real-time polymerase chain reaction analysis for 5 genes of interest in cell lines JA, JB, and AMY

\begin{tabular}{lccccc}
\hline & VEGF & CDK4 & PLK & IGF & HIF \\
\hline Normal & 1 & 1 & 1 & 1 & 1 \\
JA & 541.1932 & 102.5369 & 1770.572 & 380.038 & 352.1387 \\
JB & 230.7201 & 0.570382 & 621.6678 & 7.260153 & 75.06144 \\
AMY & 23.91759 & 0.239816 & 40.22443 & 0.659754 & 4.257481 \\
\hline
\end{tabular}

Changes in expression level relative to the normal esophageal mucosal control cell line are indicated by the values in the table. VEGF, Vascular endothelial growth factor; $C D K 4$, cyclin dependent kinase 4; PLK, polo-like kinases; IGF, insulin-like growth factor; HIF, hypoxia-inducible factor. 